\title{
Oochoristica koubeki n. sp. (Cestoda, Anoplocephalidae) from African Chamaeleo senegalensis (Chamaeleonidae) and emendation of the genus Oochoristica Lühe, 1898
}

\author{
Š. MAŠOVÁ ${ }^{1}, F$. TENORA ${ }^{1 \dagger}, V$. BARUŠ ${ }^{2}$ \\ ${ }^{1}$ Department of Botany and Zoology, Faculty of Science, Masaryk University, Kotlářská 2, 61137 Brno, \\ Czech Republic. E-mail: masova@sci.muni.cz; ${ }^{2}$ Department of Zoology and Fisheries, Faculty of Agrobiology, \\ Food and Natural Resources, Czech University of Life Sciences Prague, Kamýcká 957, 16521 Prague 6 - Suchdol, \\ Czech Republic
}

\begin{abstract}
Summary
During a survey of species diversity and ecology of selected West African vertebrates in the Niokolo Koba National Park, Senegal, two Chamaeleo senegalensis Daudin, 1802 (Chamaeleonidae) were collected and examined for parasites. A new species, Oochoristica koubeki n. sp., anoplocephalidian cestode of the genus Oochoristica Lühe, 1898 is described from the intestine of this host. The new species is related to $O$. theileri Fuhrmann, 1924; O. theileri Fuhrmann, 1924 f. major Baer, 1933; O. celebensis Yamaguti, 1954 and O. rostellata Zschokke, 1905 var. agamicolla Dollfus, 1957. All the forenamed species share characteristic strobila with proglottids wider than long. Oochoristica koubeki n. sp. differs from these species in different proportions of scolex, cirrus sac, ovarium and vitellarium, further differences are in number of testes and presence of reinforced genital atrium. Only $O$. theileri shares two last mentioned features, however it differs in shape of testes (rounded) and in distribution of testes (two clusters). The new species differs from all other species in extremely high number of egg's capsules, different host species and zoogeographic distribution. Emendation of genus diagnosis sensu Beveridge (1994) is provided.
\end{abstract}

Keywords: Oochoristica; tapeworm; chameleon; Africa; Senegal

\section{Introduction}

Chamaeleo senegalensis Daudin, 1802 (Chamaeleonidae) is a common West African savanna chameleon with distribution from Senegal to Cameroon. They are found in moist savannah habitats. They have day activity and can be found on the ground crossing roads, or in bushes and small trees (Leaché et al., 2006). Like other reptiles, chameleons host a variety of metazoan parasites. Often reptiles parasites are tapeworms from genus Oochoristica Lühe, 1898 (Linstowiinae). Eight cestode species of this genus infect- ing the intestine of chameleons have been reported from African chameleons till now. These species are mentioned in Table 1. In this paper a new African anoplocephalid tapeworm Oochoristica koubeki sp. n. from C. senegalensis is described and compared with similar species.

\section{Material and methods}

The two specimens of Chamaeleon senegalensis were examined in 2007. They were collected under the authority of Senegal's National Parks General Management. Both specimens were collected at Simenti $\left(13^{\circ} 01^{\prime} 33.4^{\prime} \mathrm{N}\right.$; $13^{\circ} 17^{\prime} 40.4^{\prime \prime} \mathrm{W}$; elevation $59 \mathrm{~m}$ ) in the Niokolo Koba National Park, Tambacounda district, East Senegal, Africa. Whole animals with opened ventral side were fixed in $96 \%$ ethanol. The gastrointestinal tract of each chameleon was removed and examined for helminths. In total, 3 fragments with scolices, and 19 fragments without scolices were obtained from the intestine of a single chameleon. Cestodes were fixed in $96 \%$ ethanol, stained in iron acetocarmine according to the method of Georgiev et al. (1986), and mounted in Canada balsam. Specimens were examined under a light microscope equipped with differential interference contrast (DIC) and a digital image analysis system (Olympus analySIS auto 5.0); drawings were made with the aid of a drawing attachment. All measurements are given in micrometres $(\mu \mathrm{m})$ unless otherwise stated. The names of reptiles follow on-line reptile database (http://www.reptile-database.org).

\section{Results}

Oochoristica koubeki n. sp.

(Figs. 1-5)

Description based on 1 fragment with scolex, and 17 strobilae fragments without scolices $(\mathrm{n}=10$, unless otherwise indicated; range, mean \pm standard deviation): Worms flat- 
Table 1. List of Oochoristica species reported from hosts of family Chamaeleonidae

\begin{tabular}{|c|c|c|c|}
\hline Oochoristica species & Host & Locality & Reference \\
\hline O. africana Malan, 1939 & $\begin{array}{l}\text { Chamaeleo namaquensis } \\
\text { Smith, } 1831\end{array}$ & South West Africa & $\begin{array}{l}\text { Prudhoe and Harris (1971) } \\
\text { Burrage (1973) }\end{array}$ \\
\hline O. agamae Baylis, 1919 & Chamaeleo sp. & Kenya & Baylis (1937) \\
\hline O. agamae Baylis, 1919 & $\begin{array}{l}\text { Chamaeleo etiennei } \\
\text { Schmidt, } 1919\end{array}$ & Zaire & Southwell and Lake (1939) \\
\hline $\begin{array}{l}\text { O. chavenoni Capron, } \\
\text { Brygoo et Broussart, } 1962\end{array}$ & $\begin{array}{l}\text { Furcifer verrucosus (Cuvier, } \\
1829)=\text { syn. Chamaeleo } \\
\text { verrucosus Cuvier, } 1829\end{array}$ & Madagascar & $\begin{array}{l}\text { Capron (1962) } \\
\text { Brygoo (1963) } \\
\text { Junius-Bourdain (2006) }\end{array}$ \\
\hline $\begin{array}{l}\text { O. courdurieri Capron, } \\
\text { Brygoo et Broussart, } 1962\end{array}$ & $\begin{array}{l}\text { Furcifer pardalis (Cuvier, } \\
1829)=\text { syn. Chamaeleo } \\
\text { pardalis Couvier, } 1829\end{array}$ & Madagascar & $\begin{array}{l}\text { Capron et al. (1962) } \\
\text { Brygoo (1963) } \\
\text { Junius-Bourdain (2006) }\end{array}$ \\
\hline $\begin{array}{l}\text { O. danielae Capron, } \\
\text { Brygoo et Broussart, } 1962\end{array}$ & $\begin{array}{l}\text { Furcifer verrucosus (Cuvier, } \\
1829)=\text { syn. Chamaeleo } \\
\text { verrucosus Cuvier, } 1829\end{array}$ & Madagascar & $\begin{array}{l}\text { Capron et al. (1962) } \\
\text { Brygoo (1963) } \\
\text { Junius-Bourdain (2006) }\end{array}$ \\
\hline O. koubeki n. sp. & $\begin{array}{l}\text { Chamaeleo senegalensis } \\
\text { Daudin, } 1802\end{array}$ & Senegal & In this study \\
\hline O. theileri Fuhrmann, 1924 & $\begin{array}{l}\text { Chamaeleo tempeli Tornier, } \\
1900\end{array}$ & $\begin{array}{l}\text { Republic of South Africa } \\
\text { Tanzania }\end{array}$ & $\begin{array}{l}\text { Della Santa (1956) } \\
\text { Spasskii (1951) } \\
\text { Schmidt (1986) }\end{array}$ \\
\hline $\begin{array}{l}\text { O. theileri Fuhrmann, } 1924 \\
\text { forma major Baer, } 1933\end{array}$ & $\begin{array}{l}\text { Chamaeleo tempeli Tornier, } \\
1900\end{array}$ & Tanzania & $\begin{array}{l}\text { Baer (1933) } \\
\text { Della Santa (1956) }\end{array}$ \\
\hline $\begin{array}{l}\text { O. theileri Fuhrmann, } 1924 \\
\text { forma minor Baer, } 1933\end{array}$ & $\begin{array}{l}\text { Chamaeleo tempeli Tornier, } \\
1900\end{array}$ & Tanzania & $\begin{array}{l}\text { Baer (1933) } \\
\text { Della Santa (1956) }\end{array}$ \\
\hline O. truncata (Krabbe, 1874) & $\begin{array}{l}\text { Chamaeleo gracilis } \\
\text { Hallowell, } 1844\end{array}$ & Uganda & Goldberg and Bursey (2008) \\
\hline O. truncata (Krabbe, 1874) & $\begin{array}{l}\text { Chamaeleo gracilis } \\
\text { Hallowell, } 1844 \text { Chamaeleo } \\
\text { etiennei Schmidt, } 1919\end{array}$ & Africa & Spasskii (1951) \\
\hline
\end{tabular}

tened dorsoventrally; strobila acraspedote. Maximum width attained in gravid segments. Scolex unarmed (Fig. 1 A), poorly demarcated from strobila, $907(\mathrm{n}=1)$ long by $822(\mathrm{n}=1)$ wide; 4 slightly oval suckers $256-278(265 \pm$ $9, \mathrm{n}=4)$ length and $202-256(233 \pm 12, \mathrm{n}=4)$ width. Neck short in length, imperceptible, $781(\mathrm{n}=1)$ width. Immature juvenile proglottids $72-123(94 \pm 16)$ long by $1460-1561(1510 \pm 26)$ wide. Ratio of immature proglottid length to width $4.92-8.18 \%(6.19 \% \pm 1.04 \%)$. Mature proglottids $367-400(382 \pm 13, \mathrm{n}=7)$ length and $1948-2118(2034 \pm 44, \mathrm{n}=7)$ width. Ratio of mature proglottid length to width $17.41-20.55 \%(18.80 \% \pm$ $0.97 \%, \mathrm{n}=7)$. Gravid proglottids wider than long, 416$1007(719 \pm 145, \mathrm{n}=15)$ long by $1663-2186(1997 \pm$ $140, \mathrm{n}=15)$ wide. Ratio of gravid proglottid length to width $22.74-55.66 \%(36.23 \% \pm 7.49 \%, \mathrm{n}=15)$. Testes oval, arranged in 1 cluster slightly narrowed under vitelline gland, occupying central region between osmoregulatory canals, mostly posterior to ovary and vitelline gland, however testes reach the posterior margin of ovary. Testes numbering $50-65(57.6 \pm 5.2)$ per proglottid, $18-51$ (31 $\pm 6)$ long by $48-82(68 \pm 9)$ wide. Cirrus sac elongated, with clear, thick external wall, narrowing markedly at proximal end where vas deferens enters, exceeding osmoregulatory canals, $233-295(262 \pm 20)$ in length and $56-75(67 \pm 5)$ in width. Ratio of cirrus sac length to mature proglottid width $11.50-14.33 \%(12.86 \% \pm$ $1.08 \%, \mathrm{n}=7$ ). Genital ducts passing between the osmoregulatory canals. Genital atrium conspicuous, sphincter like, armed, encircled and strengthened by bands of circular and radial musculature. Genital pores alternating irregularly, situated in anterior fourth of proglottid. Ovary lobulated, medial, in anterior half of proglottid, $132-224(161 \pm 18)$ long by $393-758(628 \pm$ 78) wide. Lobes of ovary not reaching lateral osmoregulatory canals. Ratio of the width of the ovary to the 

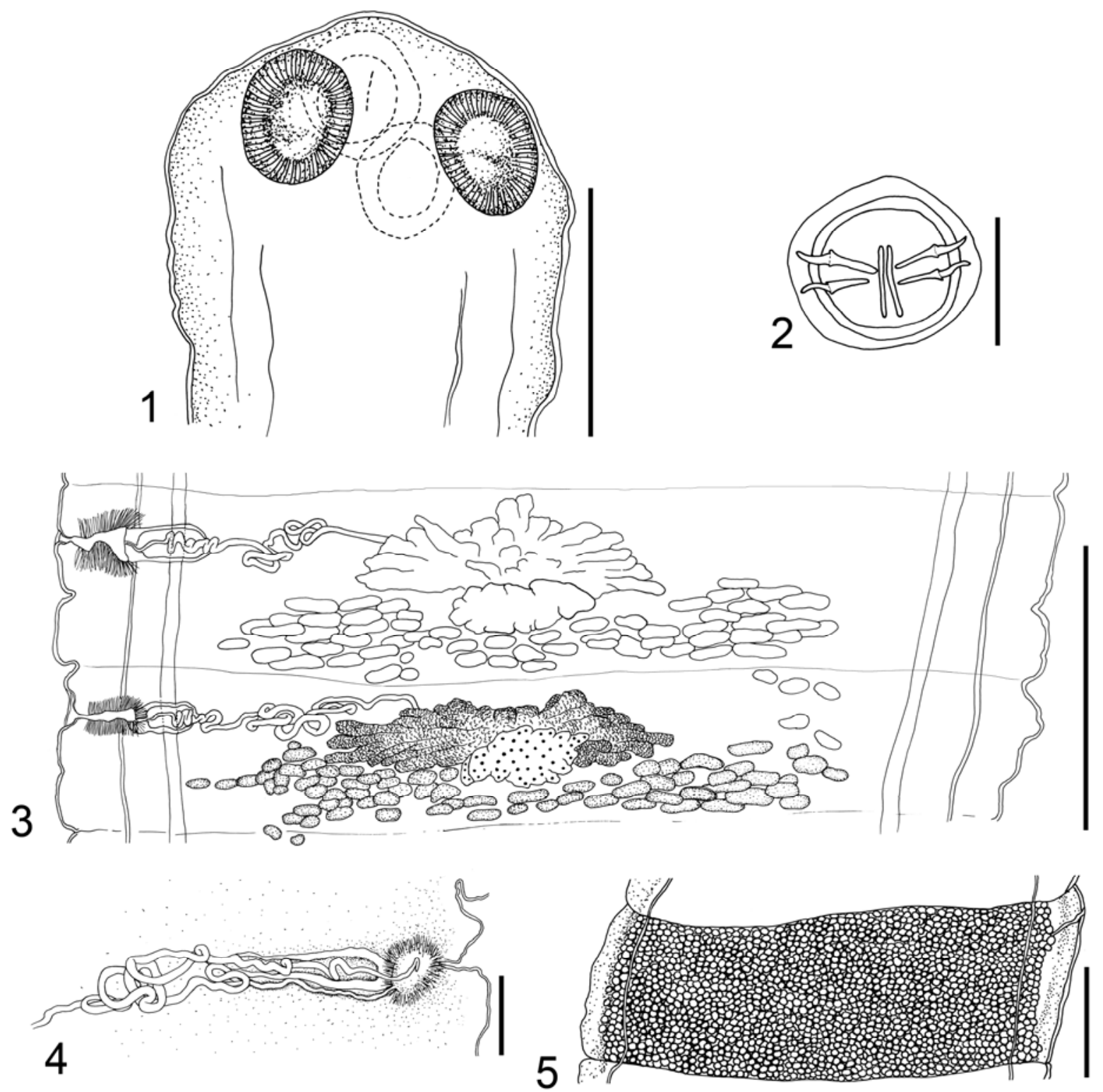

Figs. 1 - 5. Oochoristica koubeki n. sp.; line drawings. Fig. 1. Scolex. Bar $=500 \mu \mathrm{m}$; Fig. 2. Fully formed oncosphere. Bar $=50 \mu \mathrm{m}$; Fig. 3. Mature proglottids of strobilar fragment. Bar $=600 \mu \mathrm{m}$; Fig. 4. Detail of terminal genitalia. Bar $=200 \mu \mathrm{m}$; Fig. 5. Terminal gravid proglottid. $\mathrm{Bar}=500 \mu \mathrm{m}$.

mature proglottid $18.56-38.92 \%$. $(32.09 \% \pm 3.94 \%, \mathrm{n}=$ 7). Vitelline gland medial, compact, oval in shape, postovarian, $81-134(106 \pm 13)$ long by $202-347(251 \pm$ $35)$ wide, with small rounded lobules. Vitelline duct arises from dorsal surface of vitelline gland, Mehlis' gland not visible. Vagina opens into genital atrium, posterior to cirrus sac. Uterus not detectable in proglottids, replaced by eggs. Eggs located individually and embedded singly in the parenchyma of the proglottid. Number of eggs more than 1000. Whole egg with outer envelope $37-43(39 \pm 2)$ in diameter, hexacanth with inner envelope $31-38(34 \pm 2)$ in diameter, hexacanth size $24-31(27 \pm 2)$ in diameter (Fig. 4). Oncosphere hooks length $15-19$ (17 \pm 1$)$. Two dorsal and 2 ventral osmoregulatory canals present.
Taxonomic summary

Type specimens: Holotype and 19 paratypes (Cat. C-615) deposited in the Helminthological Collection of the Institute of Parasitology, the Academy of Sciences of the Czech Republic, Branišovská 31, 370 05, České Budějovice, Czech Republic.

Type host: Chamaeleo senegalensis Daudin, 1802 (Chamaeleonidae), Senegal Chameleon.

Site of infection: Small intestine.

Type locality: Simenti, Niokolo Koba National Park, East Senegal, Africa (130 $\left.01^{\prime} 33.4^{\prime \prime} \mathrm{N}, 13^{\circ} 17^{\prime} 40.4^{\prime \prime} \mathrm{W}\right)$.

Prevalence: One of two examined hosts, i.e., $50 \%$.

Intensity of infection: Three tapeworms in a single chameleon. 
Etymology: Specific epithet in honor of prof. Petr Koubek, Institute of Vertebrate Biology, Academy of Sciences of the Czech Republic, a specialist in wildlife ecology and principal investigator of the project "Species diversity and ecology of selected West African vertebrates".

Remarks

The new species is placed in Oochoristica Lühe, 1898 (Anoplocephalidae: Linstowiinae) because of the acraspedote proglottids, unarmed scolex with four suckers, genital aperture single and alternating irregularly, vagina posterior to the cirrus sac, lobed median and lightly poral ovary, median and post ovarian vitellaria, uterus ephemeral, capsules with a single egg, numerous testes, which are posterior and lateral to the vitelline gland (Spasskii, 1951; Okafor, 1988; Beveridge, 1994). About ninety species of genus Oochoristica parasitizing reptiles and mammals are currently worldwidely recognized (Bursey et al., 1996, Arizmendi-Espinosa et al., 2005; GuillénHernández et al., 2007; Mašová et al., 2010). However there exist a problem with validity and synonymy of these species and a revision of this genus is needed (Beveridge, 1994; Mašová et al., 2010). You can see older incomplete species lists and compendia for example by Meggitt (1934); Hughes (1940), Hughes et al. (1941); Spasskii (1950), Wardle and McLeod (1952), Della Santa (1956), Schmidt (1986) and others. About 20 species are distributed In the Ethiopian realm (Schmidt, 1986; Bursey et al., 1994). Out of these, 7 species are parasites of chameleons, from which 3 species are described from Madagascar. Table 1 summarizes all known data regarding occurrences of Oochoristica species in chameleon hosts. Important distinguishing features of $O$. koubeki sp. n. and other (below mentioned) similar species from all other species of Oochoristica are morphology and shape of proglottids. The new species can be readily distinguished from most species of Oochoristica by proglottids, which are wider than long and this feature persists in whole length of strobila. There exists a group of the Oochoristica species from different hosts having mature proglottids markedly wider than long: e. g., O. gallica Dollfus, 1954; O. darensis, Dollfus, 1957; O. pseudocotylea Dollfus, 1957; O. rostellata Zschokke, 1905; O. oklahomensis Peery, 1939; O. procyonis Chandler, 1942; O. chavenoni Capron, Brygoo et Broussart, 1962; O. courdurieri Capron, Brygoo et Broussart, 1962; O. danielae Capron, Brygoo et Broussart,

Table 2. Comparison of basic morphological features and measurements (in $\mu \mathrm{m}$ ) of $O$. koubeki n. sp. and morphologically most-similar species of Oochoristica

\begin{tabular}{|c|c|c|c|c|c|}
\hline Features & $\begin{array}{l}\text { O. theileri } \\
\text { Fuhrmann, } \\
1924\end{array}$ & $\begin{array}{l}\text { O. theileri Fuhrmann, } \\
1924 \text { f. major Baer, } \\
1933\end{array}$ & $\begin{array}{l}\text { O. celebensis } \\
\text { Yamaguti, } \\
1954\end{array}$ & $\begin{array}{l}\text { O. rostellata } \\
\text { Zschokke, } \\
1905 \text { var. } \\
\text { agamicolla } \\
\text { Dolfus, } 1957\end{array}$ & o. koubeki n. sp. \\
\hline Scolex & $300-400$ & $410-576$ & $650-750$ & $580-680$ & $907 \times 822$ \\
\hline Cirrus sac & 120 & $106-125 \times 57-65$ & - & $150-230$ & $233-295 \times 56-75$ \\
\hline $\begin{array}{l}\text { Genital } \\
\text { atrium }\end{array}$ & Armed & Not armed & Not armed & Not armed & Armed \\
\hline Ovarium & $200-240$ & - & $240-500$ & $120-520$ & $132-224 \times 393-758$ \\
\hline Vitellarium & $80-100$ & - & $120-260$ & $150-200$ & $81-134 \times 202-347$ \\
\hline No. of testes & $26-30$ & $30-35$ & $22-31$ & $69-80$ & $50-65$ \\
\hline $\begin{array}{l}\text { No. of testes } \\
\text { clusters }\end{array}$ & 2 & 1 & 1 & 1 & 1 \\
\hline Testes shape & Round & Slightly oval & Slightly oval & Round & Oval \\
\hline $\begin{array}{c}\text { No. of } \\
\text { capsules }\end{array}$ & $<100$ & $<100$ & $<100$ & $<100$ & $>1000$ \\
\hline Host & $\begin{array}{c}\text { Agama hispida } \\
\text { (Kaup, 1827) } \\
\text { (Agamidae) }\end{array}$ & $\begin{array}{c}\text { Chamaeleo tempeli } \\
\text { Tornier, } 1900 \\
\text { (Chamaeleonidae) }\end{array}$ & $\begin{array}{l}\text { Mabuya sp. } \\
\text { (Scincidae) }\end{array}$ & $\begin{array}{l}\text { Agama bibroni } \\
\text { Duméril et } \\
\text { Bibron, 1851 } \\
\text { (Agamidae) }\end{array}$ & $\begin{array}{c}\text { Chamaeleo } \\
\text { senegalensis Daudin, } \\
1802 \\
\text { (Chamaeleonidae) }\end{array}$ \\
\hline Locality & South Africa & central East Africa & East Indonesia & North Africa & West Africa \\
\hline Reference & $\begin{array}{l}\text { Fuhrmann } \\
\text { (1924) }\end{array}$ & Della Santa (1956) & $\begin{array}{l}\text { Yamaguti } \\
(1954)\end{array}$ & Dollfus (1954) & In this study \\
\hline
\end{tabular}


1962; O. freitasi Rêgo et Ibáñez, 1965; O. bezyi Bursey et Goldberg, 1992; O. islandensis Bursey et Goldberg, 1992; O. maccoyi Bursey et Goldberg, 1996; and O. leonregagnonae Arizmendi-Espinosa, García-Prieto et GuillénHernández, 2005. However, these species have gravid proglottids longer than wide. There exists only a small group of Oochoristica species, which don't lose ratio of side, which remain in wider than long or maximally quadratic shape. These are: $O$. theileri Fuhrmann, 1924; $O$. theileri Fuhrmann, 1924 f. major Baer, 1933; O. celebensis Yamaguti, 1954; and O. rostellata Zschokke, 1905 var. agamicolla Dolfus, 1957.

Oochoristica koubeki sp. n. can be readily distinguished from the forenamed species with persisting ratio of proglottids wider than long by following features: noticeably wider scolex and proportions of cirrus sac, ovary and vitelline folicles are separated or slightly overlapping. The new species exhibits a greater number of testes than all other species, except for $O$. rostellata var. agamicolla. Only $O$. koubeki sp. n. and $O$. theileri have a strengthened genital atrium. The new species differs from $O$. theileri in testes position. Testes of $O$. theileri form two separate fields and their shape is rounded. Contrary to this arrangement, $O$. koubeki sp. n. has oval testes forming one uninterrupted field. Further essential feature is enormous number of egg capsules, which is unique for this new species. The similar species have also different hosts. Basic distinguishing features of related species are mentioned in Table 2.

\section{Discussion}

The genus Oochoristica Lühe, 1898 was established on a basis of very low knowledge of tapeworms from the host Lacerta ocellata Daudin, 1802 [synonymum of Timon lepidus (Daudin, 1802)] from locality Algeciras in Spain. It was described by Rudolphi (1819) as Taenia tuberculata. This species is considered for genotype of the genus Oochoristica. Dollfus (1954, 1957) extensively evaluated the series of revisions, which the original diagnosis by Lühe (1898) gone through it. It should be noted that up to these days, many authors have contributed to expansion eventually to narrowing of the generic diagnosis of Oochoristica. For instance the following: Zschokke (1905), Baer (1927, 1933), Meggitt (1934), Hsü (1935), Joyeux and Baer (1936), Malan (1939), Hughes (1940), Spasskii (1951), Wardle and McLeod (1952), López-Neyra (1954), Dollfus (1954, 1957), Della Santa (1956), and Schmidt (1986). Beveridge (1994) gives the latest genus characteristics. Each author modified the diagnosis according to contemporary knowledge about number of species, their hosts and distribution. On the basis of our results and studying of literature, we have reached to the conclusion that the last generic diagnosis of Oochoristica sensu Beveridge (1994) needs emendation.

Diagnosis after Beveridge (1994): Strobila small. Proglottids acraspedote, longer than wide. Genitalia single. Genital pores alternate irregularly. Genital ducts lie between canals. Internal and external seminal vesicles absent. Testes posterior to vitellarium. Ovary central. Vagina posterior to cirrus-sac. Seminal receptacle present or absent. Uterus ephemeral. Vitellarium compact. In reptiles, mammals. Cosmopolitan. Type species O. tuberculata (Rudolphi, 1819). For synonyms see Beveridge (1994), page 357. (The parts of diagnosis in italics are emended as follows.)

Emended diagnosis

Anoplocephalidae, Linstowiinae, Oochoristica

Strobila with all proglottids wider than long, alternatively quadratic or longer than wide; gravid proglottids frequently longer than wide or rarely quadratic. Testes posterior or posterior and lateral to vitellarium. Vitellarium compact, postovarian.

\section{Acknowledgments}

The reptiles were collected under agreements and supervision of the Senegal National Parks General Management. The study was supported by Long-term Research Plan MSM 0021622416 and by the research project of the Faculty of Agrobiology, Food and Natural Resources, Czech University of Life Sciences Prague, No. MSM 604607091, both funded by the Ministry of Education, Youth and Sports of the Czech Republic and by grant No. 526/09/H025 funded by the Czech Science Foundation. We are very grateful to the 2 anonymous referees, for valuable comments and correction of the manuscript, and to Dr. František Moravec for accepting the voucher specimens for deposition in the helminth collection of the Institute of Parasitology of the Institute of Parasitology ASCR, České Budějovice, Czech Republic.

\section{References}

Arizmendi-Espinosa, M. A., García-Prieto, L., GuILLÉN-HERNÁNDEZ, S. (2005): A new species of Oochoristica (Eucestoda: Cyclophyllidea) parasite of Ctenosaura pectinata (Reptilia: Iguanidae) from Oaxaca, Mexico. J. Parasitol., 91: 99 - 101. DOI: 10.1645/GE-337R

BAER, J. G. (1927): Monographie des Cestodes de la famille des Anoplocephalidae. Bull. Biol. Fr. Belg., 10: 1 - 241 BAER, J. G. (1933): Contribution à l'étude de la faune helminthologique africaine. Rev Suisse Zool., 40: $31-84$

BAYLIS, H. A. (1937): Some parasitic worms from East African chamaeleons. Ann. Mag. Nat. Hist., Ser. 10, 19: $584-593$

BeVERIDGE, I. (1994): Family Anoplocephalidae. In: Khalil, L. F., Jones, A., Bray, R. A. (Eds) Keys to the cestode parasites of vertebrates. Wallingford, Oxon, UK, C.A.B. International, pp 315 - 366

BRYGOO, E. R. (1963): Contribution à la connaissance de la parasitologie des Caméléons malgaches. Ann. Parasitol. Hum. Comp., 38: 149 - 334, 525 - 739

Burrage, B. R. (1973): Comparative ecology and behaviour of Chamaeleo pumilis pumilis (Gmelin) and C. namaquensis A. Smith (Sauria: Chameleonidae). Ann. S. Afr. 
Mus., 61: $1-158$

Bursey, C. R., GoldberG, S. R., WoOlery, D. N. (1996): Oochoristica piankai sp. n. (Cestoda: Linstowiidae) and other helminths of Moloch horridus (Sauria: Agamidae) from Australia. J. Helm. Soc. Wash., 63: 215 - 221

Bursey, C. R., McAllister, C. T., Freed, P. S., Freed, D. A. (1994): Oochoristica ubelakeri n. sp. (Cyclophyllidea: Linstowiidae) from the South African Rock Agama, Agama atra knobeli. Trans. Am. Microsc. Soc., 113: 400 - 405

CApron, A., Brygoo, E. R., Broussart, J. (1962): Cestodes de Madagascar et des Oochoristica chavenoni n. sp., Oochoristica courdurieri n. sp., Oochoristica danielae n. sp., parasites de Caméléons. Miscellanea Helminthologica Madagascariensia. Arch. Inst. Pasteur. Madag., 31: 29 - 55

Della SANTA, E. (1956): Revision du genre Oochoristica Lühe (Cestodes). Rev. Suisse Zool., 63: 1 - 113

Dollfus, R. P. (1954): Miscellanea helminthologica maroccana XVIII. Quelques cestodes du groupe Oochoristica Auctorum récoltés au Maroc avec une liste des cestodes des hérissons (Erinaceidae) et une liste des sauriens et ophidiens (exclus. Amérique et Australie) où ont été trouvée des Oochoristica. Arch. Inst. Pasteur Maroc, 4: 657 - 714

Dollfus, R. P. (1957): Miscellanea Helminthologica Maroccana. XIX. Nouvelles récoltes d'Oochoristica chez des sauriens du Maroc Famille Linstowiidae (P. Mola 1929) Genus Oochoristica Max Lühe 1908, emendatum. Arch. Inst. Pasteur Maroc, 5(7): 272 - 299

FuHrManN, O. (1924): Two new species of reptilian cestodes. Ann. Trop. Med. Parasitol., 18: 505 - 513

Georgiev, B., Biserkov, V., Genov, T. (1986): In toto staining method for cestodes with iron acetocarmine. Helminthologia, 23: $279-281$

GoldBerG, S. R., Bursey, C. R. (2008): Helminths from three species of African chameleons. Afr. Zool., 43(2): 270 - 272. DOI: $10.3377 / 1562-7020-43.2 .270$

Guillén-Hernández, S., García-Prieto. L., ArizMENDI-EsPinOSA, M. A. (2007): A new species of Oochoristica (Eucestoda: Cyclophyllidea) parasite of Ctenosaura oaxacana (Reptilia: Iguanidae) from Mexico. J. Parasitol., 93: 1136 - 1139. DOI: 10.1645/GE-1118R.1

HsÜ, H. F. (1935): Contributions à l'étude des Cestodes de Chine. Rev. Suisse Zool., 42(4): 477 - 570

Hughes, R. C. (1940): The genus Oochoristica Lühe, 1898. Am. Midl. Nat., 23(2): $368-381$

Hughes, R. C., Baker, J. R., Dawson, C. B. (1941): The tapeworms of reptiles. Part I. Am. Midl. Nat., 25: $454-468$ Joyeux, C., BAER, J. G. (1936): Cestodes, vol 30. Faune de France. Paris, France, P. Lechevalier, 613 pp.

Junius-Bourdain, F. (2006): Caméléons: biologie, élevage et principales affections (Chameleons: biology, husbandry and main diseases). $\mathrm{PhD}$ thesis, France, Alfort: École nationale vétérinaire d'Alfort (National Veterinary
School of Alfort)

KrabBE, H. (1879): Cestodes collected in Turkestan by A. P. Fedchenko. In Fedchenko's travels in Turkestan, v. 3, pt. 2, Vermes, pt. 1. Izvest. Imp. Obsh. Liub. Estestvozn., Moskva, 34(1): 1 - 23

LeAChÉ, A. D., RÖDEL, M.-O., LinKeM, C. W., DiAZ, R. E., Hillers, A., FuJITA, M. K. (2006): Biodiversity in a forest island: reptiles and amphibians of the West African Togo Hills. Amphib. Reptile Conserv., 4: 22 - 45. DOI: 10.1514/journal.arc.0040018

LÓPEZ-NEYRA, C. R. (1954): Anoplocephalidae. Rev. Ibér. Parasitol., 14: 13 - 130, 225 - 290, 303-396

LÓPEZ-NeYRA, C. R. (1955): Anoplocephalidae. Rev. Ibér. Parasitol., 15: 33 - 84

LÜHE, M. (1898): Oochoristica nov. gen. Taeniadarum (Vorläufige Mitteilung). Zool. Anz., 21: 650-652

Malan, J. R. (1939): Some helminths of South African lizards. Onderstepoort J. Vet. Sci. Anim. Ind., 12: 21 - 74

MAŠOVÁ, Š., TENORA, F., BARUŠ, V., KOUBEK, P. (2010): A new Anoplocephalid (Cestoda) from Tarentola parvicarinata (Lacertilia: Gekkonidae) in Senegal (West Africa). J. Parasitol., 96: 977 - 981. DOI: 10.1645/GE-2237.1

MegGitT, F. J. (1934): On some tapeworms from the bullsnake (Pityopsis sayi), with remarks on the species of the genus Oochoristica (Cestoda). J. Parasitol., 20: 181 - 189 OKAFOR, F. C. (1988): Oochoristica agamae Baylis, 1919 (Eucestoda, Linstowiidae) in one reptile and two bat species from Nsukka (Anambra State, Nigeria). Misc. Zool., 12: $11-12$

Prudhoe, S., Harris, M. T. (1971): Helminths from chameleons in southern Africa. Rev. Bot. Zool. Bot. Afr., 84: $334-343$

RUdOLPHI, K. A. (1819): Entozoorum synopsis cui accedunt mantissa duplex et indices locupletissimi. Berlin, Germany, Berolini: Sumtibus A. Rücker, 811 pp.

SCHMIDT, G. D. (1986) CRC handbook of tapeworm identification. CRC Press, Inc., Boca Raton, Florida, USA, 675 pp. SOUTHWELL, T., LAKE, F. (1939): On a collection of Cestoda from the Belgian Congo, with an introduction by $\mathrm{J}$. Schwartz. Ann. Trop. Med. Parasit., 33: 107 - 123

SPASSKII, A. A. (1951): Anoplocephalate, tapeworms of domestic and free living animals. Moskva, Russia, Akademiya Nauk SSSR, 735 pp. [in Russian]

Uetz, P., Hallermann, J., HoŠEK, J. (1995): The Reptile Database. Retrieved November 2010 from http://www.rep tile-database.org

WARDle, R. A., MCLEOD, J. A. (1952): The zoology of tapeworms. Minneapolis, Minnesota, USA, The University of Minnesota Press, $780 \mathrm{pp}$.

YAMAGUTI, S. (1959): The cestode parasites of vertebrates, vol 2. New York, USA, Interscience Publishers, 860 pp.

ZschOKKe, F. (1905): Das genus Oochoristica Lühe. Z. Wiss. Zool., 83: $53-67$ 